\title{
KRITIK TERHADAP TEORI SPIRAL OF SILENCE: KOMUNIKASI MASYARAKAT MADURA DALAM KONFLIK SUNNI-SYI'AH DI SAMPANG
}

\author{
Ferry Adhi Dharma \\ Magister Ilmu Komunikasi Program Pascasarjana UNS \\ ferryadhidharma@gmail.com
}

\begin{abstract}
The sunni-shiite conflict that occurred in Sampang, Madura has yet to be resolved. Therefore, this study aims to determine the process to fight the opinion that a conflict occurred between the two. The research was conducted in the Karanggayam village, Omben and Blu'uran village, Karang Penang, Sampang, Madura and mansions Puspa Agro Sidoarjo with the phenomenological method. That is, the phenomenon under study will be illustrated by personal experience of informants through interviews. To determine the validity of the data, then the triangulation on the data obtained. Results are the conflicts caused by differences of opinion between the two groups regarding the moral values of Islam. As migrant groups, Shiites openly against the public opinion which is believed by the local community (Sunni). The above measures, social isolation and threats carried out by the Sunnis that Shi'ites leave Shi'ism and move to the Sunnis. Nevertheless, Shiites remained adamant and against the social isolation. The action taken by the Shi'ite group contradicts with the assumption of spiral of silence theory, the theory which explains that there is a person's tendency to adhere to public opinion for fear of being ostracized.
\end{abstract}

\begin{abstract}
Abstrak
Konflik Sunni-Syiah yang terjadi di Sampang, Madura sampai saat ini belum dapat diselesaikan. Oleh karena itu penelitian ini bertujuan untuk mengetahui proses pertarungan pendapat yang terjadi hingga menimbulkan konflik diantara keduanya. Adapun penelitian ini dilakukan di desa Karanggayam, Omben, dan desa Blu'uran, Karang Penang, Sampang, Madura dan rumah susun Puspa Agro Sidoarjo dengan metode fenomenologi. Artinya, fenomena yang diteliti akan digambarkan dengan pengalaman pribadi informan melalui wawancara mendalam. Untuk mengetahui keabsahan data, maka dilakukan triangulasi sumber pada data yang didapat. Hasil yang ditemukan adalah konflik tersebut terjadi akibat adanya perbedaan pendapat diantara kedua kelompok mengenai nilai-nilai ajaran Islam. Sebagai kelompok pendatang, Syi'ah secara terang-terangan melawan pendapat umum yang diyakini oleh masyarakat sekitar (Sunni). Atas Tindakan tersebut, berbagai ancaman dan isolasi sosial dilakukan oleh kelompok Sunni agar kelompok Syi'ah meninggalkan ajaran Syiah dan berpindah ke Sunni. Kendati demikian, Syiah tetap bersikukuh dan melawan isolasi sosial tersebut. Tindakan yang diambil oleh kelompok Syi'ah bertentangan dengan asumsi teori spiral keheningan, dimana teori tersebut menjelaskan bahwa ada kecenderungan seseorang untuk patuh terhadap pendapat umum karena takut dikucilkan.
\end{abstract}

Keywords: Courage Communication, Conflict, Spiral of Silence. 


\section{PENDAHULUAN}

Sejauh ini banyak masyarakat di luar Madura yang tidak mengatahui dan mengenal Madura secara baik dan benar. Bahkan, Madura acap kali dijadikan sebagai bahan lelucon yang dilekatkan pada stereotip dan prasangka yang buruk. Kasar dan kolot misalnya. Ada perberbedaan mendasar dalam memaknai kasar dan tegas, serta kolot dan cinta pada budaya atau ajaran agama.

Minimnya pemahaman komunikasi antar budaya, berkembangnya stereotip, prasangka, rasisme, dan etnosenterisme yang ada pada diri masyarakat Indonesia hendaknya diperhatikan dan dipahami secara serius. Stereotip "Madura yang keras" dan prasangka buruk masyarakat akan menimbulkan kecemasan komunikasi yang berkelanjutan. Bagi orang-orang yang memiliki pengetahuan seperti itu, pilihan untuk menjalin hubungan komunikasi dengan orang Madura akan menjadi pilihan yang sangat sulit. Jika pengetahuan tersebut tidak diperbaiki, maka bukan tidak mungkin akanterjadipengucilankomunikasidansosial terhadap orang Madura secara komunal.

Komunikasi yang terjadi tidak akan pernah tulus dan jujur. Akan muncul etnosentrisme yang tinggi dalam menjalin hubungan satu sama lain, serta terjadi kerusakan komunikasi multikultural yang akan menambah daftar panjang konflik Suku, Agama, Ras, dan Antar golongan (SARA) di Indonesia.

Sampai saat ini konflik SARA masih menjadi teror disintegrasi yang menakutkan. Belum juga terhindar dari stereotip keras, masyarakat Madura sudah dihadapkan dengan konflik satu etnik antara kelompok Sunni dan Syiah yang terjadi di Sampang pada 26 Agustus 2012 silam. Konflik tersebut sampai saat ini belum dapat diselesaikan oleh pihak manapun dan mengambang tanpa ada solusi yang jelas.

Muqoyyidin (2012: 315) menjelaskan bahwa konflik Sunni-Syiah Sampang tergolong pada konflik perbedaan pendapat dalam satu agama yang berubah menjadi konflik sosial dan fisik.
Perbedaan pada tiap individu, baik perbedaan pendapat dan budaya yang dibawa oleh tiap anggota masyarakat merupakan bagian dari aktifitas sosial yang tidak dapat dipisahkan. Perbedaan-perbedaan tersebut dapat mengganggu hubungan sosial dan menimbulkan konflik seperti penjelasan Whiters dan Lewis berikut:

"Relationships can be put at risk because of the differences and similarities that we all have. Because differences can lead to conflict, we have a taboo in our society about talking about them. Trouble is, if we never get a chance to talk to people about what we see as differences, we never get a chance to question some of the assumptions we make about people who may be different from us." (Whiters dan Lewis, 2003: 19).

Terkadang individu dalam masyarakat tidak mengetahui secara pasti perbedaan yang dimaksud. Oleh karena itu, memahami perbedaan kelompok atau orang lain merupakan pilihan yang baik untuk dilakukan.

Kasus Sampang, Sunni adalah kelompok pribumi (mayoritas) yang meniscayakan Islam sebagai pandangan hidup masyarakat, sedangkan Syi'ahadalah kelompokpendatang yang berpendapat bahwa pandangan hidup masyarakat sekitar tidak didasarkan pada ajaran Islam, melainkan hasil konstruksi realitas sosial yang dilakukan oleh kiai-kiai. Dari perbedaan pendapat itu, muncul wacana sesat antar kelompok dan isolasi komunikasisosial yang berujung pada konflik (Dharma, 2016: 72).

Pertarungan pendapat tersebut dimainkanolehmasing-masingpemimpinkelompok. Pemimpin Sunni terus menyampaikan isu kesesatan Syi'ah, sementara pemimpin Syi'ah tetap bertahan dengan pesan-pesan yang dibawa dan mencoba untuk melakukan konstruksi sosial pada masyarakat sekitar agar pendapatnya dapat diterima.

Tindakan kelompok Syi'ah tersebut berpengaruh pada hubungan sosial yang telah dibangun. Kiai-kiai Sunni menghimbau pada warga sekitar untuk tidak melewati 
rumah anggota kelompok Syi'ah, dan menerima segala makanan yang diberikan. Kendati demikian, pengucilan atau esklusi yang terjadi tidak serta-merta terjadi karena kesalahan kelompok Sunni. Dengan ajaran pembaharuan yang dibawa oleh Tajul, kelompok Syi'ah bersifat esklusif dan sesekali menyampaikan pesan provokatif. Kelompok Syiah merasa lebih berpikiran maju dan pintar dibandingkan dengan kelompok Sunni (Dharma, 2016: 74).

Secara teoritik, menyuarakan pendapat yang berlawanan, atau bertindak tidak sesuai dengan pendapat umum akan menimbulkan bahaya isolasi. Dominasi pendapat umum tersebut memaksa individu atau kelompok untuk bersikap dan bertindak sesuai dengan ketentuan umum (Neumann, 1974: 44).

Hal yang dilakukan oleh kelompok Syi'ah tersebut bertentangan dengan kaidah teori spiral of silence yang dikemukakan oleh Elisabeth Noelle-Neumann. Dalam penelitian awal, Noelle-Neumann dalam Shoemaker, Breen, \& Stemper (2000: 67) mendefinisikan opini publik sebagai tekanan untuk menyesuaikan diri dengan pendapat umum, dan dua teorinya pertama untuk menunjukkan peran yang takut akan adanya isolasi dalam spiral keheningan.

Pertama, sebagai makhluk sosial. Kebanyakan orang takut terisolasi dari lingkungan mereka. Mereka ingin menjadi populer dan dihormati. Kedua, untuk menghindari isolasi dan agar tidak kehilangan popularitas dan harga diri, orang terus mengamati lingkungan mereka sangat erat. Mereka mencoba untuk mengetahui pendapat dan mode perilaku yang lazim, dan yang pendapat dan mode perilaku menjadi lebih populer. Mereka berperilaku dan mengekspresikan diri sesuai di depan umum.

Fenomena keberanian kelompok Syi'ah dalam melawan pendapat umum dapat dijadikan sebagai kritik terhadap penjelasan Noelle-Neumann di atas. Keberagaman budaya yang ada di Indonesia menjadi alasan kuat mengapa tidak semua teori yang berkembang di negara lain dapat diaplikasikan di Indonesia. Ini menjadi kekayaan bangsa Indonesia yang pantas untuk dikaji dan diperkenalkan pada dunia.

Littlejohn dan Foss (2011: 424) menyampaikan bahwa ketika ada teori yang tidak relevan, maka siapapun boleh mengkritik dan menggugurkannya dengan memberikan teori baru. Dengan demikian, teori baru tersebut akan menjadi pandangan baru. Teori tidak selalu benar, dan teori baru tersebut juga dapat digugurkan oleh orang lain. Namun yang harus diingat adalah tanggungjawab atas kritik dan penemuan teori baru tersebut.

Identitas komunikasi masyarakat Madura dalam konflik Sunni-Syi'ah yang dijelaskan dalam tulisan ini diharapkan menjadi pemicu akademisi ilmu komunikasi untuk mengkaji identitas komunikasi budaya-budaya lain yang ada di Indonesia. Selain menambah khazanah keilmuan ilmu komunikasi, pengkajian tersebut dapat meminimalisir hambatan dan konflik komunikasi yang dapat berujung pada konflik SARA.

\section{METODE}

Penelitian ini dilakukan di Desa Karang Gayam, Kecamatan Omben, Sampang, Desa Bluuran, Kecamatan Karang Penang, Sampang, dan komplek rumah susun pasar puspa agro Sepanjang, Sidoarjo. Responden yang ada di Sampang ialah kelompok Sunni, sementara kelompok Syi'ah berada di Sidoarjo.

Penelitian dilakukan secara langsung selama kurang lebih enam bulan, yakni pada bulan Februari 2015 sampai dengan bulan Agustus 2015. Dalam kurun waktu tersebut telah dilakukan observasi awal di lokasi penelitian, wawancara mendalam dan observasi partisipan pada informan di dua lokasi penelitian.

Metode dan pendekatan yang digunakan dalam penelitian ini adalah fenomenologi. Pemilihan tersebut didasarkan pada fenomena konflik yang sampai saat ini belum terselesaikan dan menjadi pengalaman hidup bagi siapapun yang terlibat dalam konflik. Edmun Hussrel (1983: 5) menyebutnya sebagai kognisi alami. Dimana hubungan manusia dan pengalaman itu sendiri bersifat kontingen.

Penelitian akan ditekankan pada sub- 
jektifitas pengalaman hidup dari informan penelitian, baik dari kelompok Sunni maupun kelompok Syi'ah tanpa adanya pengaruh oleh konsep atau teori. Hal tersebut dilakukan untuk menghindari adanya hipotesis dan dugaan yang merusak data alami tersebut.

Secara keseluruhan penelitian ini melakukan wawancara pada 11 informan. Dari 11 informan tersebut, dua diantaranya adalah aparat pemerintah yang pernah bersentuhan secara langsung dengan konflik, satu anggota kelompok Syi'ah, seorang warga Karang Penang, dua warga Karang Gayam, satu warga Madura, satu tengkulak tembakau dari luar Madura yang sering berbisnis di wilayah konflik, dan tiga Pegawai Negeri Sipil (PNS) yang bekerja di sekitar area konflik. Dari 11 informan tersebut, hanya tiga yang diwawancarai dan dikaji secara mendalam, yaitu: satu anggota kelompok Syi'ah, satu aparat pemerintah, dan satu anggota kelompok Sunni. Semua wawancara dilakukan secara diam-diam demi keabsahan data penelitian.

Metode fenomenologi yang digunakan dalam penelitian ini dinilai sudah tepat untuk menggambarkan pengalaman informan terhadap konflik yang sudah dialami. Namun karena lokasi konflik sangat susah untuk dimasuki, informan dan data pendukung yang didapat belum terlalu kuat untuk menganalisis data fenomenologis yang didapat.

Perlu diketahui jika pemerintah dan tokoh ulama setempat sangat konsen terhadap permasalahan tersebut dengan membentuk tim lima untuk mendampingi dan mengarahkan semua peneliti yang ingin masuk ke lokasi konflik. Ada ketakutan pada keabsahan data jika penelitian ini dibantu oleh tim lima, menimbang bahwa tugasutama tim lima sesungguhnya untuk mengawasi anggota Syi'ah yang sudah dibai'at.

\section{HASIL DAN PEMBAHASAN Kronologi Konflik Sunni-Syi’ah di Sampang}

Secara garis besar, kronologi isolasi sosial dalam penelitian ini dapat digambarkan dengan gambar berikut:

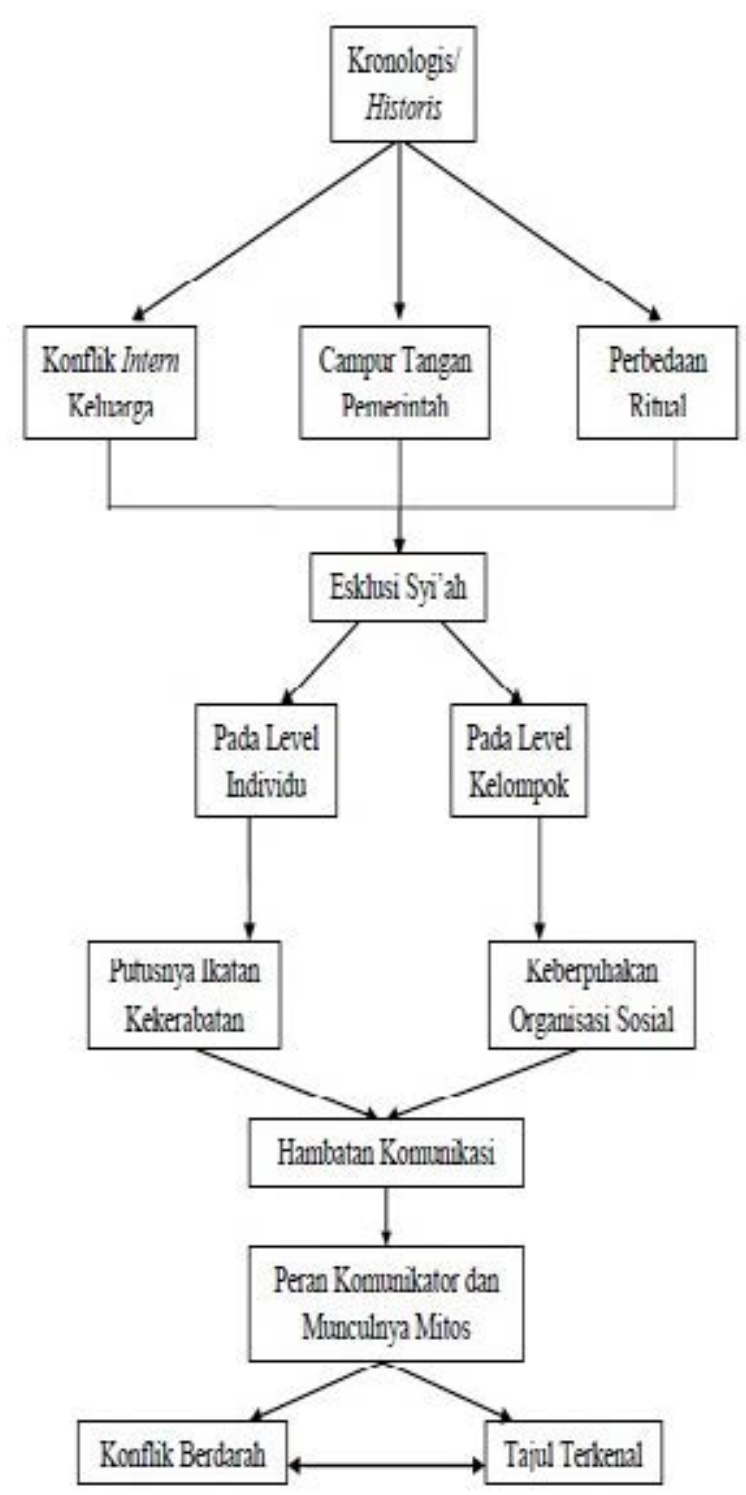

Penolakan dan isolasi sosial terhadap Syi'ah justru berawaldari keluarga dan kerabat dekat pimpinan Syi'ah sendiri. Tersebut lah Ali Karrar sebagai orang yang sangat menolak ajaran Syi'ah diajarkan di Sampang. Ali Karrar sendiri merupakan kerabat dekat Tajul dan kiai yang disegani di Madura. Oleh karena itu, pengaruhnya sangat besar dalam membentuk isolasi atau esklusi dan konflik antara kelompok Sunni dengan Syi'ah yang terjadi di Sampang, Madura.

Sebenarnya permasalahan yang terjadi dapat diredam dan tidak berujung pada konflik dan pembunuhan. Konflik fisik terjadi justru karena Rois (adik Tajul) keluar dari Syi'ah dan menghasut kiai-kiai setempat untuk segera mengusir Syi'ah dari daerah tersebut.

Keputusan Rois untuk keluar dari Syi'ah 
dikarenakan rasa sakit hati atas tindakan Tajul yang menikahkan santriwatinya dengan santri Tajul tanpa sepengetahuan Rois. Setelah dilakukan penelusuran, ternyata Rois memiliki perasaan suka terhadap santriwatinya tersebut.

Pada akhirnya Rois sangat vokal dalam aksi penolakan terhadap Syi'ah karena mendapat dukungan dari kiai-kiai dan masyarakat sekitar. Bahkan Rois dapat menghagemoni masyarakat sekitar untuk menyerang kelompok Syi'ah dan mengusir Syi'ah dari Sampang, meskipun Rois tidak terbukti bersalah atas tindakan tersebut.

Selain terjadi konflik internal dalam keluarga pimpinan Syi'ah, penelitian ini juga menemukan keberpihakan pemerintah terhadap masalah tersebut. Tidak diakuinya Syi'ah sebagai salah satu aliran dalam Islam juga dinyatakan oleh Kepala Bidang Sosial Bakesbangpol Sampang. Hal tersebut ditunjukkan dengan tidak diijinkannya penelitian dengan judul Sunni-Syiah, dan harus diganti dengan aliran Tajul Muluk.

"Aliran sesat gak boleh. Keputusan pengadilan tingkat pertama Pengadilan Negeri Mahkama Agung berbunyi aliran Tajul Muluk bukan aliran sesat ustad Tajul. Kemarin kan kata ibu katanya Sunni Syi'ah gak boleh. Syi'ah ganti aliran Tajul Muluk atau aliran sesat. Aliran Tajul Muluk, bukan sesat. bukan aliran sesat, Sunni Syiah gak boleh, aliran sesat gak boleh. Aliran Tajul Muluk, jangan aliran sesat. ini-ini, pola jaringan komunikasi aliran Tajul Muluk, jadi nanti bunyinya itu. (Kabid. Sosial Bakesbangpol Sampang, pada 14.04.2015, di kantor Bakesbangpol, Sampang).

Jika diganti menjadi aliran Tajul Muluk, maka kasus yang terjadi di Sampang bukan aliran Syi'ah yang sesat, namun aliran sesat yang dibawa oleh Tajul Muluk. Hal tersebut sangat berbeda dengan fakta yang ada. Menurut laporan Kontras Surabaya (2012), Tajul Muluk dan Iklil adalah anggota Ikatan Jamaah Ahlul Bait Indonesia (IJABI), yang notabene merupakan organisasi milik
Syi'ah.

Selain itu, pemerintah bekerja sama dengan pemuka agama dari kelompok Sunni untuk membentuk tim lima atau yang bertugas mengawasi kelompok Syi'ah yang sudah dibai'at dan mendampingi semua penelitian yang dilakukan di lokasi tersebut.

"Tim 5 itu siapa saja ya pak? Ustad Hasan, Ustad Nasir, Mat Bahri, Ustad Dlawi alias Pak Sanah, dan Ustad Syaifuddin." (Informan 5, pada 16.04.2015, di desa Geding Laok, Karang Penang, Sampang)

Semua anggota tim lima merupakan pemuka agama di daerah tersebut. tim lima tersebutterdiri dari Ustad Hasan, Ustad Nasir, Mat Bahri, Ustad Dlawi alias Pak Sanah, dan Ustad Syaifuddin. Adapun satu nama yang diberikan tugas sebagai juru bicara dalam kasus tersebut adalah Apel Munaaji.

Apel Munaji akan menjelaskan latar belakang terjadinya konflik kepada setiap peneliti yang melakukan penelitian di daerah tersebut. Peneliti sempat diarahkan untuk menemui Apel Munaji saat membrikan surat rekomendasi penelitian dari Bakesbangpol Sampang pada aparat setempat.

Ternyata tim lima sendiri sengaja dibentuk untuk melakukan pendampingan pada setiap peneliti yang ingin meneliti kasus tersebut. Tim lima adalah tim yang disediakan oleh Bakesbangpol Sampang dengan alasan kenyamanan dan keamanan penelitian.

"Jadi tolong ini kalau saya ijinkan satu jangan sampai menciptakan sikon tidak kondusif. Mewawancarai orang, apa karena situasinya tau sendiri kan, sebagian masyarakat belum boleh pulang. Nah seumpama mau kesana koordinasi dengan kita-kita, kita bisa bantu. Kalau setuju dengan beberapa persyaratan itu saya akan beri rekomendasi. Nanti mau ke daerah mana itu tolong rekomendasi ini juga nanti diberikan ya ke kepolisian, kodim, camat, harus diberi. Ya, baik saya bisa membantu, tau arahnya kesini minta 
tolong, kita pertemukan dengan tim 5. Jarang saya baca proposal seperti ini" (Informan 3, pada 14.04.2015, di kantor Bakesbangpol, Sampang).

Selain berpengaruh pada tingkat keabsahan data, pendampingan tersebut dapat diartikan sebagai pengawasan dan pembatasan penelitian ataupun orang asing yang ingin mengeksplor permasalahan tersebut.

Sebelum terjadi konflik Tajul-Rois, dan campurtangan pemerintah, di lokasi tersebut sudah terjadi perang pendapat terhadap nilai-nilai yang dianut oleh masing-masing kelompok. Kelompok Syi'ah mengklaim bahwa ajaran yang dianut merupakan ajaran pembaharuan yang lebih maju dari kelompok Sunni.

Latar belakang pendidikan dijadikan sebagai perbedaan yang mencolok oleh kedua kelompok, dimana pemimpin kelompok Sunni lebih mengedepankan pendidikan pondok pesantren sedangkan kelompok Syi'ah selalu meneyerukan pentingnya pendidikan formal hingga pada level perguruan tinggi. Dengan perbedaan tersebut pada akhirnya membuat kelompok Syi'ah merasa lebih esklusif dan mapan.

Niat belajar yang tinggi dari kelompok Syiah juga dapat dilihat dari kemauan untuk belajar bahasa Jawa. Hal tersebut dilakukan untuk bersosialisasi dengan masyarakat sekitar tempat kelompok Syiah diungsikan.

Pendapat Syi'ah mengenai wajib belajar bertentangan dengan Pendapat Sunni menjadi dan masalah yang menghambat hubungan komunikasi diantara keduanya. Syi'ah secara frontal juga ingin merubah kebiasaan warga sekitar seperti menikah di usia dini dan mewajibkan kelompoknya untuk wajib belajar setinggi-tingginya. Bahkan salah satu pendatang yang sudah lama tinggal di daerah tersebut ingin memanfaatkan keuntungan dari pandangan hidup masyarakat sekitar.

"Aku wes pernah kerjo neng honorer neng mburi iki, tapi ora krasan, gaji ne sitik. Walah mas, neng kene cewek 15 tahun akeh sing wes rondo. Aku ngko tak nikah wong kenen wae, lah dibelanjani 10 ewu wes seneng, rotoroto nikah siri mas neng kene. Kae mau kancaku ngomae gedek meh robo tapi wes haji, masalah gengsi agomo nomer siji mas. Padahal neng kene yo kacau, akeh maling barang." (Informan 4, pada 15.04.2015, di Omben, Sampang).

Dalam bahasa Indonesia. "Saya sudah pernah bekerja jadi tenaga honorer di belakang ini, tetapi tidak bertahan lama atau nyaman, gajinya sedikit. Walah mas, disini perempuan 15 tahun banyak yang sudah janda. Saya nanti menikah dengan orang sini saja, lah dikasih uang belanja 10 ribu saja sudah senang, ratarata disini menikah siri mas. Tadi teman saya rumahnya dari kayu hampir roboh tetapi sudah haji, masalah gengsi agama nomer satu mas. Padahal disini juga kacau, banyak maling." (Informan 4, pada 15.04.2015, di Omben, Sampang).

"Njenengan ngertos mboten konflik sunni-syiah niku? Pas kejadian kulo mboten ten mriku. Tapi ngeten loh mas. Memang masalah agomo niku nomer siji ten mriku, lah wong kulo sholat mawon dikomentari kale rencang kulo; kok sholate cepet pak, sholat model opo? Nggeh kulo jawab, walah, wong aku iki loh gak sepiro paham agomo, pahamku yo ngene iki, mangkane ajarono." (Informan 9, pada 19.07.2015, di Sidoarjo).

Dalam bahasa Indonesia. "Anda mengetahui konflik Sunni-Syi'ah itu? Waktu kejadian itu saya sedang tidak di lokasi mas. Memang masalah agama itu disana nomer satu, lah saya sholat saja dikomentari sama orang sana; kok sholatnya cepat pak? Ya saya jawab, walah, orang saya ini loh tidak seberapa paham agama, saya hanya paham sebatas ini, maka dari itu ajari saya." (Informan 9, pada 19.07.2015, di Sidoarjo).

Hukum tradisional yang diberlakukan di daerah tersebut diidentikkan dengan hukum 
Islam, oleh karena itu warga sekitar mulai enggan berkomunikasi dengan kelompok Syi'ah yang dinilai tidak patuh dan hormat terhadap peraturan tidak tertulis yang berlaku di daerah tersebut.

Isolasi sosial yang dilakukan masyarakat sekitar tidak dipedulikan oleh kelompok Syi'ah. Akibat pemikiran yang dianggap lebih maju tersebut, kelompok Syi'ah semakin tidak percaya dengan nilai-nilai agama yang diyakini oleh masyarakat. Menurut kelompok Syiah, nilai-nilai keagamaan yang dipercaya dan dilakukan oleh kelompok Sunni merupakan hasil konstruksi kiai-kiai yang sangat merugikan masyarakat.

Pada akhirnya isolasi sosial yang terjadi tidak serta merta karena kesalahan kelompok Sunni. Dengan ajaran pembaharuan yang dibawa oleh Tajul, kelompok Syiah bersifat lebih esklusif dan sesekali menyampaikan pesan provokatif. Kelompok Syi'ah merasa lebih berpikiran maju dan pintar dibandingkan dengan kelompok Sunni.

\begin{abstract}
"Katanya kelompok syiah boleh balik kalau masuk sunni? Iya dari awal itu, dari awal. Apakah ini murni salahnya orang sunni? gak juga. Mereka juga salah. Mereka dari kelompok Syi'ah yang sudah agakmaju bilang:wah, kalau ikut ustad sana miskin." (Informan 1, pada 16.02.2015, tempat dirahasiakan).
\end{abstract}

Karena tindakan esklusif tersebut kelompok Syi'ah semakin dibenci oleh masyarakat sekitrar. Disamping itu, masyarakatsekitarjuga menuruti permintaan kiai agar tidak melewati rumah orang Syi'ah dan menerima makanan yang diberikan oleh kelompok Syi'ah. Komunikasi diantara keduanya menjadi terputus. Terputusnya komunikasi tersebut dimanfaatkan oleh masing-masing kiai untuk semakin menguatkan realitas yang dibagun. Sunni menguatkan keseesatan Syiah, dan Syi'ah menguatkan opini kekolotan Sunni.

Pertarungan pendapat yang terjadi tidak seimbang. Kelompok Sunni sebagai mayoritas dapat memenangkan opini masyarakat dengan cepat. Pada akhirnya terbentuk opini bahwa Syi'ah merupakan ajaran yang sesat dan wajib dimusuhi. Mengetahui hal tersebut anggota kelompok Syi'ah tidak bergeming dan tetap bersatu. Kelompok Syi'ah tetap bersikukuh untuk mempertahankan pendapat yang tidak populer tersebut.

Kelompok Syi'ah tidak merasa tertekan dan segera menyesuaikan diri dengan masyarakat meskipun permasalahan membesar hingga Tajul Muluk dipanggil oleh Forum Musyawarah Ulama (FMU) SampangPamekasan untuk menghentikan ajarannya dan pindah ke ajaran Sunni.

Isolasi secara individu tersebut bukan hanya dilakukan oleh masyarakat sekitar pada anggota kelompok Syi'ah, namun sudah pada tingkat pengucilan dalam keluarga. Terjadi semacam perang saudara di Sampang yang berubah menjadi perang antar kelompok Sunni dengan Syi'ah.

Bahkan ajaran Syiah tidak boleh disebarluaskan dan diberikan ruang tersendiri didaerah perbatasandesayang sebagian besar tanahnya adalah perbukitan dan jauh dari pemukiman warga. Salah satu warga sekitar yang diwawancarai menyebutkan bahwa keputusan tersebut sengaja diambil oleh tokoh masyarakat setempat agar ajaran ini tidak dapat disebarkan secara luas dan terangterangan. Selain itu anggota kelompok Syi'ah juga tidak diperbolehkan untuk bersekolah di Madrasah milik kelompok Sunni, dan mendapatkan fasilitas umum lainnya.

Organisasi Kemasyarakatan (Ormas) yang diharapkan menjadi penengah dalam konflik tersebut nyatanya berpihak pada kelompok mayoritas. Dialok dari masyarakat luar dibatasi oleh organisasi sosial yang ada. Selain melakukan pembatasan komunikasi antara kelompok Sunni dengan Syi'ah, organisasi sosial tersebut membatasi komunikasi masyarakat sekitar dengan orang luar agar tidak dimasuki oleh pengaruh lain. Kendati demikian, ada Ormas serupa dari luar daerah sedang menaruh simpatik dan ingin segera menyelesaikan konflik. Hal tersebut dapat dilihat dalam kutipan wawancara berikut:

"Mas ferry yang mau jadi..... Mas bisa menghubungi pak subhi dari NU 
omben. Kenapa bu? Semua kegiatan harus lewat beliau mas. Biar bisa ngajar buta huruf disana ya harus ijin dulu ke pak subhi. Baik bu, kalau begitu saya minta kontaknya ya. (Informan 7, pada 06.06.2015, Via telepon seluler).

"Waduh mas, begini mas, kita hanya ditugaskan memberi bantuan logistik pada korban konflik, sekarang kan sudah di Sidoarjo. Ini baru saja ada orang-orang muda dari NU katanya mau mengadakan perdamaian. Katanya sduah keliling ke dinas-dinas untuk meminta pendapat dan kerjasama membuat program bersama. Mas ikut mereka saja. Tempatnya masih rawan loh mas, belum ada yang berani meneliti disana." (Informan 6, pada 14.04.2015, di Sampang).

Organisasi sosial tersebut memiliki peran dalam menghadirkan dan menyelesaikan konflik yang terjadi di Sampang. Berikut adalah pertemuan yang dilakukan sesuai data penelitian Kontras Surabaya pada tahun 2012:

“1. Pada 24 Februari 2006, atas inisiatif Abuya Ali Karrar Shinhaji, sejumlah ulama dari beberapa tempat di Madura berkumpuldi rumah almarhum H. Sya'bi dan mengundang Ustad Tajul Muluk dengan agenda 'klarifikasituduhan sesat atas ajaran Syiah yang dibawa Tajul Muluk'. Pertemuan ini juga dihadiri $H$. Fadlilah Budiono, Bupati Sampang, dan juga Imron Rosyidi Kakandepag Sampang. Karena Tajul tidak hadir, maka pertemuan ini dilanjutkan pada 26 Februari 2006.

2. Pada 26 Februari 2006, sebagai kelanjutan dari pertemuan tgl 24 Ferbuari, sejumlah kiai yang kali ini diketuai Abd. Wahhab Adnan bersama dengan ketua MUI Sampang pada masa itu Mubassyir dan Kapolsek Omben mengundang Tajul Muluk di Masjid Landeko' Karanggayam di tempat kediaman kakek Tajul (Kiai Nawawi). Resminya pertemuan inibernama Forum
Musyawarah Ulama (FMU) SampangPamekasan. Pertemuan ini dihadiri oleh semua yang hadir pada pertemuan 26 Februari 2006, mereka berkumpul kembali untuk mendengarkan jawaban Tajul Muluk. Tajul Muluk hadir dalam pertemuan ini menyatakan bahwa syiah yang diajarkan tidak sesat, merupakan salah satu mahzab yang diakui dalam dunia islam, dan dirinya tidak bersedia keluar dari syiah. Karena tidak bisa merubah keyakinan Tajul, akhirnya FMU mengeluarkan keputusan yang isinya sebagai berikut:

"Mengajak pimpinan syi'ah ja'fariyyah (Tajul Muluk Makmun) untuk segera kembali ke jalan ahlu al-sunnah wa aljama'ah dan sesepuh terdahulu untuk menghindari terjadinya bentrokan faham dan fisik di kalangan masyarakat awamyangsangatdikhawatirkanterjadi. Dan karena Tajul Muluk telah menolak tawaran FMU tersebut, maka FMU tidak bertanggungjawab atas segala apa yang terjadi dan memasrahkan persoalan kepada aparat yang berwajib. FMU menghimbau kepada Majlis Ulama Indonesia (MUI) empat kabupaten di Madura agar segera menyatakan fatwa tentang bahaya aliran-aliran sesat termasuk aliran syi'ah yang meragukan keabsahan kitab suci al-qur'an, keadilan sahabat Nabi dan berghulu (berlebihlebihan) dalam ahlu al-bait (keluarga Nabi)".

Berger dan Luckmann (1966: 69) menyebutkan bahwa manusia dan lingkungan sosial adalah satu kesatuan yang saling berhubungan. Keduanya menjadi penting karena saling membutuhlan. Manusia sebagai makhluk sosial hendaknya memanfaatkan lingkungan sosialnya dengan baik dan memberikan manfaat bagi dirinya dan orang lain. Disinilah konstruksi sosial yang dibangun akan terlihat.

Modal sosial yang tinggi membuat kiai berpeluang dalam membentuk identitas kelompok, bahkan identitas etnins Madura secara keseluruhan. Fatwah sesat bukan hanya 
direspon oleh masyarakat sekitar, namun mayoritas masyarakat Madura yang sama-sama memiliki ikatan emosional dengan norma agama tersebut. Oleh karena itu, tidak dapat dipungkiri jika Syi'ah di Sampang pada akhirnya dimusuhi oleh ulama-ulama di Madura, dan masyarakat Madura.

Ada fakta bahwa sebenarnya masyarakat yang ikut menyerang banyak didatangkan dari luar daerah tersebut. Rata-rata dari mereka tidak mengetahui alasan yang jelas mengapa harus ikut menyerang kelompok Syi'ah.

Dengan memanfaatkan momen idhul fitri masyarakat yang ikut menyerang tersebut meminta maaf pada kelompok Syi'ah dan berjanji untuk segera menemukan jalan damai dengan kiai-kiai yang telah menggerakkan mereka.

Sebenarnya ada solusi yang baik jika komunikan mau berlapang dada untuk segera mengakui kekejaman konflik dan kemudian sepakat untuk berdamai. Namun, hingga saat ini belum terlihat tanda akan tumbuhnya kesadaran tersebut, meskipun kedua belah pihak masih memiliki ikatan kekerabatan atau yang disebut orang Madura sebagai tretan.

Baik kelompok Sunni maupun Syi'ah masih memiliki ikatan kekerabatan, karena sama-sama telah hidup berdampingan di tempat tersebut sejak dahulu. Bedanya, kelompok Sunni merupakan aliran kepercayaan yang lebih dulu ada dan dianut oleh semua masyarakat. Oleh karena itu, kelompok Syi'ah berpandangan bahwa tidak akan terjadi konflik diantara mereka, karena perbedaan ajaran tersebut.

Wiyata dalam bukunya yang berjudul mencari Madura menyampaikan sebuah pendapat dalam bahasa Madura: Orèng dhaddhi tarètan, tarètan dhaddhi orèng (artinya: orang lain yang bukan keluarga dapat dianggap sebagai saudara, sebaliknya saudara sendiri dapat dianggap sebagai bukan keluarga) (Wiyata, 2013: 19).

Tali persaudaraan antar masyarakat telah dirusak oleh pesan persuasif kiai Sunni untuk memusuhi kelompok Syi’ah. Konflik keluarga telah diubah menjadi konflik antar keluarga-keluarga yang ada di daerah tersebut.

Pendapat diatas menunjukkan betapa lemahnya ikatan kekerabatan dalam kultur kekerabatan di Madura. Bagi masyarakat Madura ikatan kekerabatan bukan merupakan hal yang sakral dan harus dijaga baik-baik. Konflik yang terjadi dapat dijadikan sebagai salah satu bukti pembenaran dari pendapat diatas.

\section{Etosentrime, Konteks Budaya Rendah dan Sejarah Sosial Masyarakat Madura}

Perlu diketahui bahwa sejarah pergolakan Syi'ah di Indonesia berhubungan erat dengan sejarah politik Islam yang ada di Indonesia dan Timur Tengah. Para pemimpin Masyumi telah menjadi sosialis agamis pada tahun 1950an, sekarang mereka beraliansi dengan kekuatan yang paling konservatif di dunia Islam -Arab Saudi. Ini lah yang membuat mereka sangat membenci Revolusi Iran dan Syi'ah. Dewan Dakwah, terutama Mohammad Natsir mensponsori publikasi-publikasi yang sangat anti Syi'ah (beberapa di antaranya dilis oleh pengarang Dewan Dakwah sendiri) (Bruinessen, 2013: 149).

Kelompok penguasa mayoritas ini pada akhirnya dapat menghagemoni pemeluk Islam di Indonesia (yang Sunni) dengan menyatakan bahwa paham Syi'ah merupakan ajaran yang sesat. Pada akhirnya, berbagai aksi penolakan terjadi, yang salah satunya menghasilkan konflik berdarah di Sampang, Madura.

Stereotip sesat yang dilekatkan pada kelompok Syi'ah, dan stereotip kolot yang dilekatkan pada kelompok Sunni menumbuhkan prasangka buruk satu sama lain. Kelompok Sunni enggan berkomunikasi dengan kelompok Syi'ah karena sudah dianggap sesat, sedangkan kelompok Syi'ah tidak ingin berkomunikasi dengan kelompok Sunni karena dinilai kolot dan terlalu mencampuri urusan pribadi dengan Tuhan. Pada akhirnya terbentuk etnosentrisme pada kedua kelompok, yang diwujudkan dengan ketidaktulusan komunikasi dan rasa saling 
tidak percaya.

Menurut Samovar, Porter, \& McDaniel (2009), etnosentrisme dapat menjadi hambatan komunikasi yang serius. Hal tersebut dapat dilihat dalam penjelasan berikut:

There can be serious consequences if you engage in negative ethnocentrism at the same time as you are trying to practice successful intercultural communication. One of the major interpersonal consequences of ethnocentrism is anxiety. The argument is simple and is clearly enunciated by Gamble and Gamble: "The more ethnocentric you are, the more anxious you are about interacting with other cultures; when we are fearful, we are less likely to expect a positive outcome from such interactions, and less willing to trust someone from another culture."(Samovar, Porter, E McDaniel, 2009: 181).

Semakin etnosentris kedua kelompok, maka yang akan ditimbulkan adalah kecemasan saat keduanya berinteraksi. Komunikasi yang dilakukan tidak akan tulus. Masing-masing kelompok menginginkan adanya keuntungan dari komunikasi yang dilakukan, dan kurang bersedia untuk mempercayai kelompok lainnya.

Etnosentrisme diatas pada akhirnya memunculkan manipulasi informasi. Ketidakpercayaan dalam komunikasi dapat dijelaskan oleh Burgon, et. al, dengan tahapan berikut: Pertama, Burgoon, et. al (dalam McCornack, et. al., 1996) menganggap bahwa penerima yang stategis menggunakan berbagai dimensi informasi, ketika menafsirkan pesan dan menilai kredibilitas komunikator. Ada bukti kuat bahwa individu tidak memproses isyarat pesan dengan waspada dan berpendidikan. Kedua, informasi yang diungkapkan dalam pesan yang menipu secara substansial berbeda dari informasi yang benar, yakni perbedaan yang akan mengakibatkan penerima berinisiatif mendeteksi ulang pesan yang diterima. Ketiga, ketika penerima pesan mendeteksi adanya manipulasi informasi, mereka akan beranggapan telah diperdaya oleh komunikator.
Ketidaktulusan komunikasi antar kelompok semakin diperparah dengan pola komunikasi masyarakat Madura yang tegas. Ketegasan komunikasi yang dilakukan oleh masyarakat tidak didasari dengan pengetahuan yang cukup mengenai apa yang sebenarnyadiperdebatkan. Masyarakathanya percaya dengan apa yang disampaikan oleh masing-masing tokoh kiai. Baik kelompok Sunni maupun Syi'ah secara terang-terangan telah menunjukkan rasa tidak suka satu sama lain dengan sikap yang tegas dan spontan. Terjadi komunikasi yang negatif dan saling serang pendapat di antara kedua kelompok yang kebablasan dan berujung pada konflik.

Rifa'i (dalam Fitriani, 2013: 54) menyebutkan bahwa sebenarnya sifat orang Madura itu sangat individualistis tetapi tidak egois, sangat menekankan kemandirian, ulet dan tegar, suka berterus terang, suka berpetualang, sangat menghormati tetua dan guru, dan sebagainya. Suka berterus terang dalam kajian ilmu komunikasi antar budaya dikenal sebagai konteks budaya rendah. Edwart T. Hall (1976: 85) menyebutkan bahwa ada dua kontreks dalam budaya yang disebut budaya konteks rendah dan budaya konteks tingggi. Budaya konteks rendah diidentikkan dengan keterbukaan informasi yang dimiliki oleh budaya beserta anggota budayanya. Sedangkan budaya konteks tinggi akan lebih tertutup dalam menyampaikan informasi dan berkomunikasi.

Fenomena keberanian dan ketegasan masyarakat Madura dalam berkomunikasi berkaitan dengan sejarah sosial masyarakat yg telah terjadi. Ross (dalam Judith dan Nakayama, 2010) memberikan contoh sejarah penindasan yang dialami oleh pemeluk Katolik di lingkungan sosial dan pekerjaan memicu terjadinya konflik di Irlandia Utara. Perlu diketrahui bahwa sejarah sendiri berpengaruh besar pada kehidupan di masa sekarang.

Contoh tersebut diperkuat dengan pendapat Edmunn Husserl (1983) yang menyatakan bahwa pengalaman seseorang berhubungan secara kontingen dengan manusia itu sendiri. Dalam lingkup sosialbudaya, komunikasi dialektik dilihat sebagai 
tindakan kolektif dari individu-individu dan masyarakat yang memiliki kesamaan sejarah.

Pada masa Vereenigde Oostindische Compagnie(VOC) pulau Maduradibagidalam tiga kabupaten, yang batas-batasnya sampai paruh kedua abad ke-19 tetap tidak berubah, yaitu: Madura Barat dan Madura Timur (Pamekasan dan Sumenep). Madura barat lebih banyak dikekang dari pada kabupatenkabupaten yang di Timur. Hubungan antara kompeni dan Madura Barat di atas kertas dikualifikasi sebagai hubungan antara "raja" dan pengikut yang mendapat pinjaman tanah, sedangkan dalam kasus Sumenep dan Pamekasan, hubungan tersebut tidak ada sama sekali (Jonge, 1989: 51-52).

Karena kesetian raja-raja Madura pada VOC, raja-raja tersebut diberi wewenang dan kebebasan untuk mengatur daerahnya sendiri. Raja-raja tersebut semakin bersikap sewenang-wenang pada rakyat. Tekanan tersebut meliputi dua hal. Selain membayar pajak, penduduk diwajibkan menjalankan jasa tenaga pribadi bagi sang raja, pemegang tanah lunggguh, dan bagi para kepala desa. Semua pria dewasa "yang sahat jasmani" dapat dikenai jasa tenaga wajib (V.d.M, 1890: 110, dalam Jonge, 1989: 70).

Komunikasi masyarakat Madura, khususnya Sampang dan Bangkalan menjadi lebih spontan, baik verbal maupun nonverbal. Ketika masyarakat sekitar (Sampang) tidak suka dengan kelompok Syi'ah, maka yang terjadi adalah saling serang pendapat dan konflik.

Sejarah sosial tersebut turut melanggengkan isolasi sosial yang terjadi. Terbentuknya spontanitas, ketegasan, dan tindak kekerasan dalam berkomunikasi telah melekat pada aktifitas sosial masyarakat sekitar. Kendati telah merusak hubungan sosial dan kekerabatan yang sudah lama terjalin, fenomena tindak komunikasi yang spontan dan tegas dari masyarakat Madura tersebut dapat dijadikan sebagai salah satu simbol kekayaan budaya komunikasi yang ada di Indonesia.

Masyarakat Madura sendiri sangat tidak suka dilecehkan. Bagi orang Madura, pesan yang melecehkan harga diri akan berakibat pada konflik yang serius. Wiyata (2013: 4) menyebutkan ketika orang Madura merasa malu, maka yang terjadi adalah perlawanan yang sangat keras dan dapat mengakibatkan kehancuran hubungan sosial yang sudah dibangun.

Bagi orang Madura, hidup tidak akan ada artinya jika tiga hal yang disakralkan (agama, wanita, dan harta) dilecehkan oleh orang lain. Hal tersebut dapat dilihat dalam kutipan wawancara berikut:

\section{"Konfliknya itu disebelah mana sih pak? Itu diperbatasan Karanggayam dan Bluuran di bukit-bukit itu. Syiah memang hanya diajarkan ditempat itu, seperti dikucilkan di bukit situ, waktu diserang ya sudah dikepung dari mana- mana. Ada 3 yang dibela sama warga sini sampai mati, wanita atau istri, harta, dan agama mas. Ini kan masalah menyangkut agama, apalagi kiai yang minta." (Informan 5, pada 16.04.2015, di desa Geding Laok, Karang Penang, Sampang)}

Kehormatan bagi orang Madura adalah nilai luhuryang harus dijunjung tinggi, jikaitu diremehkan atau bahkan direndahkan maka akan muncul sifat tersinggung yang akhirnya mengarah pada konflik dan kekerasan (carok). Kehormatan tersebut meliputi: harga diri (ego), wanita, harta (hak milik) dan agama. Masalah kehormatan, harga diri, dan status adalah masalah keluarga. Oleh karena itu setiap anggota keluarga harus menjaga nama baik keluarganya, bahkan harus rela berkorban jiwa-raga demi nama baik keluarga. Dengan demikian dalam penyelesaian konflik tidak jarang melibatkan keluarga bahkan teman dekat. Masalah yang belum terselesaikan oleh orang tua biasanya diwariskan secara turun-temurun kepada anak laki-laki (Filayati, 2013: 61-62).

Selain dikenal pemberani, masyarakat Madura juga dikenal religius dengan simbolsimbol Islam yang melekat (sarung dan songkok). Hal itu dapat dikaitkan dengan letak geografis pulau Madura yang tidak jauh darisejarah peradaban dan penyebaranagama 
Islam di Jawa -Gresik. Selain Pekalongan, Gresik disebut oleh Raffles (1817: 4) sebagai salah satu kota dengan jumlah pemuka agama dan penganut Islam yang cukup besar pada waktu itu.

Madura dan Jawa sejatinya memiliki ikatan sosiologis-religius sejak lama. Sejak runtuhnya Majapahit dan lahir kerajaan Islam (Demak) di Jawa, pulau Madura dijadikan sebagai basis penyerangan dalam perjuangan, yang juga bermotif ekonomi, terhadap beberapa daerah di ujung timur jawa yang tetap "kafir" dan didukung oleh Bali (De Graaf dan Pingeaud, 1974: 170-171, dalam Jonge, 1989: 46-47).

Keberanian dan ketegasan Tajul dalam mempertahankan pendapat yang dinilai melecehkan ajaran masyarakat sekitar membuat kelompok Syi'ah diberi label kafir dan dijatuhi hukuman yang sangat berat (isolasi dan konflik) oleh masyarakat

Setelah dilantik menjadi ketua Ikatan Jama'ah Ahlul Bait Indonesia (IJABI) Madura, Tajul menjadi semakin berani dan terbuka dalam berdakwah. Pengikut Tajul tetap setia dan bersatu melawan ancaman yang ada. Bahkan anggota Tajul menganggap bahwa hal ancaman-ancaman yang diterima tidak berpengaruh pada aktifitas kelompok Syi'ah. Pengikut Syi'ah pun berkembang tidak hanya di desa Karanggayam, kecamatan Omben, namun sudah bertambah ke desa Blu'uran. kecamatan Karang Penang.

\section{Pembangunan Identitas dan Kolektifitas Kelompok Syi'ah}

Nilai kebenaran yang diyakini oleh masing-masing kelompok telah dijadikan pedoman hidup dan identitas sosial bagi masing-masing kelompok. Kelompok Sunni menciptakan identitas sebagai kelompok aliran Islam yang menghormati nilai-nilai luhurdan budaya, sedangkan kelompokSyi'ah menciptakan identitas sebagai kelompok aliran Islam yang maju dan berwawasan luas. Dengan demikian terciptalah dua kelompok yang saling bertentangan.

Pandanganhiduporang Maduramemang tidak dapat dipisahkan dari nilai-nilai ajaran agama Islam. Rifa'i (2007) dalam Wiyata (2013: 3) menyebutkan suatu fakta sosiologis bahwa hampir seluruh masyarakat Madura adalah penganut agama Islam. Ketaatan mereka pada agama Islam merupakan penjatidirian penting bagi mereka. Ini dapat diidentifikasi dari cara mereka berpakaian sampèr (kain panjang), kebaya, dan burgo' (kerudung) bagi kaum perempuan, sarong (sarung) dan songko' (kopiah atau peci) bagi kaum laki-laki sudah menjadi lambang keislaman khususnya di wilayah pedesaan. Oleh karena itu, identitas keislama merupakan suatu hal yang amat penting.

Dari pandangan hidup itu akhirnya terbentuk strata sosial dari dimensi agama, yaitu kiai, yang menempati posisi teratas, kemudian bindarah, yaitu orang yang sudah lulus dari pondok pesantren, dan yang terakhir adalah santri. Pembagian tersebut berdasar pada tingkatan ilmu pengetahuan mereka mengenai agama.

Posisi kiai nampaknya penting untuk dimiliki oleh masyarakat Madura. Jonge (1989: 243-244) pernah meneliti sejarah perkembangan Islam di Madura dengan salah satu temuan data bahwa pernah ada persaingan dalam perebutan strata sosial tertinggi (kiai) di Madura. Syarqowi, seorang kiai pada waktu itu, dalam waktu singkat telah menjadi kiai muda yang sangat terpandang. Pengetahuan dan kanujela (kuasa ajaib) yang pada waktu itu menjadi segi terpenting dari kepemimpinan rohani, berhasil dikuasai hingga melampaui pemuka keagamaan setempat. Syarqowi adalah kiai muda yang berasal dari Jawa. Kiai muda tersebut kurang memperhatikan adat dan kebiasaan orangorang Madura. Iri hati dan intrik-intrik dari pemuka agama tradisional membuatnya harus meninggalkan desa tempat Syarqowi berdakwah. Kendati tidak melibatkan dua kelompok yang berbeda, fenomena tersebut menjadi bukti bahwa kiai memiliki pengaruh yang besar di masyarakat.

Sama hal nya dengan kisah Syarqowi, tidak akan mudah diijinkan seorang tokoh baru naik kasta dalam waktu yang singkat dan cara yang mudah. Taklik mengenai ajaran Syi'ah yang sholat sambil berjoget 
dijadikan oleh kiai setempat sebagai senjata untuk memusuhi kelompok Syi'ah.

Ketakutan kiai sekitar pada perkembangan ajaran Syi'ah dikarenakan adanya masyarakat sekitar yang mulai bergabung dengan kelompok Syi'ah. Berkurangnya penganut Sunni akan melemahkan pengaruh hirarki sosial-ekonomi kiai di daerah tersebut.

Jika kisah Syarqowi masuk dalam ranah sentimen antar pribadi, konflik antara Sunni dengan Syi'ah dapat diidentifikasi sebagai konflik antara kelompok kita dengan kelompok mereka. Oleh sebab itu diperlukan cara penyelesaian konflik yang tepat dan rumit, yang bisa jadi melibatkan banyak pihak dari kelompok-kelompok sosial lainnya.

Individu-individu dalam kelompok "kita" akan bertindak secara kolektif dalam konfliktersebut. Samovar, Porter, \& McDaniel (2009: 68) menyampaikan sebuah pepetah bahwa individu dalam keluarga, yang dalam ini adalah satu kelompok sosial-budaya tidak akan dapat dipisahkan ibarat jari dan tangan.

Samovar, Porter, \& McDaniel (2009: 15) menyebutkan fungsi komunikasi dalam komunikasi antar budaya sebagai berikut: (1) mendapatkan informasi mengenai komunikan, (2) memenuhi kebutuhan antarpribadi, (3) membentuk identitas pribadi, dan (4) mempengaruhi orang lain.

Makna dan norma yang dibangun oleh kelompok Sunni di Sampang didasarkan pada sinkretisme atau penyatuan keyakinan kelompok tersebut dengan kebudayaan lokal. Aturan agama dan budaya menjadi satu-kasatuan yang diwariskan secara turuntemurun untuk memaknai identitas sosial kelompok tersebut. Contoh konkritnya adalah ritual memperingati maulid nabi Muhammad S.A.W secara komunal dari rumah ke rumah. Selain memiliki makna identitas yang mengistimewakan nabi Muhammad S.A.W, ritual tersebut juga menjadi norma agama dan sosial untuk masyarakat sekitar.

Ritual keagamaan tersebut dinilai Tajul sebagai ritual yang merugikan rakyat miskin.
Oleh sebab itu Tajul menghimbau agar ritual tersebut diadakan di satu tempat secara bersama-sama dan biaya dapat ditanggung secara bersama-sama.

Ajaran Tajul tersebut sangat tidak disukai oleh tokoh-tokoh agama setempat. Selain berimplikasi terhadap nilai-nilai ritual, orang yang paling dirugikan oleh pesan Tajul Muluk tersebut adalah kiai. Jika ritual diubah sesuai dengan arahaan Tajul Muluk, maka penghasilan kiai otomatis akan mengalami penurunan.

Pada akhirnya pesan mengenai kesesatan Syi'ah terus diproduksi oleh kiai setempat dan didistribusikan pada masyarakat melalui dakwah-dakwah. Dengan adanya label sesat dari kiai dan masyarakat, kelompok Syi'ah tidak merasa takut dan tetap mempertahankan ajaran yang dipercaya. Hal tersebut dapat dilihat dari hasil wawancara berikut:

Katanya boleh kembali kesana kalau pindah ajaran Sunni? Lah ya itu, itu urusan sendiri-sendiri sama Allah, yang dibawa sendiri-sendiri. Itu dijaga, jangan diurusi orang-orang yang lain. (Informan 8, pada 23.07.2015, di rumah susun Puspa Agro, Sidoarjo).

Sebenarnya, tujuan utama dari pembentukan identitas sosial adalah membangun persepsi yang dirasionalkan. Persepsi identitas kelompok labih diutamakan daripada fakta mengenai identitas tersebut (Tajfel, 1981: 129).

Prasangkadanstereotipdijadikansebagai senjata utama dalam membentuk persepsi tersebut. Konstruksi realitas yang dilakukan oleh masing-masing kelompok mengilhami terbentuknya eskalasi konflik. Eskalasi tersebut berkembang ketika masyarakat sekitar dihimbau untuk menjauhi rumah kelompok Syi'ah dan menolak pemberian makanan dari anggota kelompok Syi'ah.

Stereotip sesat dan kolot pada akhirnya tidak hanya dibangun oleh tokoh kiai. Bahkan mayoritas anggota kelompok dengan sendirinya menjadi produsen dan distributor dalam penyebaran stereotip yang menimbulkan prasangka negatif tersebut.

Menanggapi sikap anti-pati tersebut, 
kelompok Syi'ah dihimbau oleh Tajul Muluk dan Iklil untuk tetap solid dan saling menjaga satu sama lain. Tajul Muluktidak menyerukan padakelompoknyauntuk merubah keyakinan dari Syi’ah menjadi Sunni.

Keberanian yang dicontohkan oleh Tajul benar-benar dipahami oleh kelompok Syi'ah. Tidak terpikir dalam benak kelompok Syi'ah untuk pindah ajaran dengan tetap yakin dan percaya bahwa ajaran yang dianut adalah ajaran yang benar, serta berharap agar Allah S.W.T segera menyambung kembali hubungan Sunni dan Syi'ah yang telah putus.

\section{Keberanian Komunikasi Syi'ah: Dimusuhi dan Dikenal}

Ada peran besar yang dimainkan oleh masing-masing opinion leader dalam konflik Sunni-Syi'ah yang terjadi di Sampang, Madura. Kendati demikian, tokoh sentral yang mendadak menjadi sangat populer adalah Tajul Muluk (kelompok Syi'ah).

Bagi kelompok Syi'ah, Tajul Muluk merupakan sosok pemimpin yang berani, dan berwawasan ke depan. Sedangkan bagi kelompok Sunni, Tajul Muluk merupakan orang yang membawa aliran sesat dalam ajaran Islam. Setelah meninggalnya kiai Makmun (ayah dari Tajul), di lokasi tersebut terbagi dalam dua kelompok yang saling kontra. Hal tersebut dikarenakan adanya intrik dalam kontestasi politik ataupun perebutan kekuasaan berdakwah yang semakin kentara.

Hal tersebut sangat diketahui oleh Tajul. Kendati demikian, Tajul tetap meyakini, melakukan, dan menyebarkan ajaran Syi'ah pada masyarakat. Keberanian dan ketegasan Tajul tersebut diikuti oleh semua anggota Syi'ah dan sangat dibenci oleh masyarakat.

Atas keberanian Tajul tersebut, nama Tajul Muluk semakin dikenal oleh jamaah Syi'ah yang ada di Indonesia. Tajul Muluk dan Iklil mendadak dikenal oleh masyarakat dunia karena pemberitaan media pada waktu itu.

Dalam kajian ilmu komunikasi, tindakan Tajul tersebut dapat dijelaskaan dengan teori tindakanberalasan.Teoriiniakanmenjelaskan mengapa dan bagaimana kelompok Syi'ah melakukan esklusi komunikasi yang sudah diketahui akan berujung pada konflik berdarah yang merugikan kelompoknya.

Teori tindakan beralasan dapat menjelaskan dan memprediksi perilaku moral yang terjadi. Nyatanya, memasukkan aspek; keyakinan tindakan, hasil evaluasi, dan sikap yang menuju pada prilaku serta aspek nomatif seperti: kepercayaan normatif, motivasi untuk patuh, dan norma subyektif telah mewakili semua variabel pribadi dan sosial yang terlibat dalam perilaku moral (Vallerand., et. al, 1992: 100).

Secara historis, keyakinan tindakan dari kelompok Syi'ah akan dilihat dari dua masa ketokohan-Tajul dan Makmun. Ada perbedaan yang mencolok antara Tajul dan Makmun (pendiri Syi'ah di Sampang) dalam berdakwah; Tajul yang berdakwah secara terang-terangan, dan Makmun yang berdakwah secara diam-diam.

Disamping sebagai tokoh kiai yang sangat disegani oleh masyarakat, Makmun juga lebih suka mengikuti arus yang ada di lingkungannya dengan tidak mengkritisi ajaran masyarakat sekitar. Setidaknya ketokohan Makmun tersebut telah membuat hubungan Syiah dengan Sunni menjadi harmonis.

Setelah kiai Makmun wafat dan digantikan oleh putran-putranya (Tajul Muluk, Iklil, dan Rois), dengan cepat kelompok Sunni diubah oleh kiai-kiai setempat menjadi kelompok superior. Semua kegiatan sosialkemasyarakatan dikuasai oleh kelompok Sunni, dan kelompok Syi'ah tidak dapat berbuat banyak dan selalu dipaksa mematuhi aturan-aturan normatif yang telah ditetapkan oleh masyarakat sekitar.

Beragam ancaman dan paksaan tersebut sama sekali tidak membuat kelompok Syi'ah gentar. Adapun alasan kuat mengapa kelompok Syi'ah berani bertindak melawan kelompok Sunni karena ustad Rois (adik Tajul Muluk) adalah orang terpandang, baik dari status sosial maupun ekonomi. Ketika para angggota kelompok Syi'ah takut akan terjadi gesekan sosial dengan kelompok Sunni, Rois 
selalu menjadi orang pertama yang memberi jaminan keamanan.

Setelah Rois keluar dari Syi'ah dan berbalik menyerang Syi'ah, kelompok Syi'ah tetap berani karena Tajul Muluk memberikan contoh reaktif terhadap pengucilan komunikasi yang selama ini dilakukan oleh kelompok Sunni terhadap kelompok Syi'ah.

Fenomena diatas jelas sangat berbeda dengan kaidah teori spiral keheningan yang dikemukakan oleh Elizabeth Noelle-Neumann. Ketakutan isolasi sosial membuat orang cenderung mengikuti pendapat umum, yang terbagi dalam tiga poin berikut:

"• Society threatens deviant individuals with isolation; fear of isolation is pervasive. - This fear of isolation causes individuals to try to assess the climate of opinion at all times. P Public behavior is affected by public opinion assessment." (-Masyarakat mengancam individu yang menyimpang dengan isolasi; menanamkan ketakutan terisolasi. -Karena takut terisolasi menyebabkan individu mencoba untuk menilai iklim pendapat setiap saat. •Perilaku Masyarakat dipengaruhi oleh penilaian opini publik.) Noelle-Neumann (1991, 1993) (dalam West \& Turner, 2010: 414).

Poin pertama dari paparan Noelle-Neumann di atas dapat dibenarkan. Memang benar ada ancaman isolasi sosial yang dilakukan oleh kelompok Sunni pada kelompok Syiah. Seperti yang sudah dijelaskan diatas bahwa ancaman tersebut berupa stereotip sesat, pembatasan wilayah, dan lain sebagainya. Hal tersebut dilakukan agar kelompok Syi'ah meninggalkan ajaran Syiah dan berpindah menganut ajaran masyarakat sekitar (Sunni).

Dengan adanya ancaman-ancaman tersebut, Tajul dan anggota kelompok Syi'ah lainnya sama sekali tidak merasa takut. Bahkan Tajul menjadi semakin berani ketika namanya dikenal luas oleh penganut Syi'ah dari luar Madura. Atas keberanian Tajul tersebut, Tajul dijadikan sebagai ketua IJABI Madura oleh pengurus IJABI pusat. Selain itu, Tajul berhasil memperkuat persatuan dan kesatuan dalam kelompoknya dengan membangun identitas dan kolektifitas kelompok yang didasarkan pada kemajuan berpikir.

Pada akhirnya kelompok Syi'ah merasa benar dan ingin menyadarkan kelompok Sunni yang dinilai kolot dan hanya menuruti taklik buta dari kiai setempat. Kelompok Syi'ah dengan berani dan tegas tetap menjalankan ajaran yang diyakini tanpa memperdulikan iklim pendapat yang ada di masyarakat. Hal tersebut membuktikan bahwa kelompok Syi'ah sama sekali tidak terpengaruh oleh penilaian opini publik, meskipun pada akhirnya terjadi konflik batin dan fisik.

\section{Simpulan}

Esklusi komunikasi terjadi karena adanya konflik keluarga, campur tangan pemerintah, dan perbedaan pendapat dalam ajaran yang diyakini oleh masing-masing kelompok. Konflik menjadi semakin besar ketika Rois, yang notabene adalah adik Tajul Muluk memutuskan untuk keluar dari Syi'ah, bergabung dengan kelompok Sunni, dan berbalik memusuhi kelompok Syi'ah.

Kendati demikian, konflik tidak murni karena kesalahan kelompok Sunni. Karena merasa berpikiran lebih maju, kelompok Syi'ah lebih suka hidup esklusif dalam kelompoknya. Komunikasi pun semakin terputus dan terjadi kerenggangan hubungan sosial diantara keduanya.

Konflik menjadi semakin rumit karena pemerintah tidak bersikap netral terhadap kasus tersebut. Ada diskrimisasi terhadap kelompok Syi'ah karena ada peran sentral dari tokoh kiai dalam pelaksanaan pemerintahan di Sampang.

Selain itu ada hambatan komunikasi yang dipengaruhi oleh sejarah sosial dari masyarakat sendiri. Masyarakat Madura dikenal memiliki ketegasan dalam berkomunikasi, baik verbal maupun nonverbal. Hal tersebut dapat terlihat dari semangat pemberontakanMaduraterhadappenindasan yang sering dialami. Komunikasi masyarakat Sampang lebih spontan karena jauh dari 
pusat pemerintahan kerajaan Madura, dan lebih tertindas. Ketika masyarakat sekitar tidak suka dengan kelompok Syi'ah, maka secara langsung diwijudkan dengan hujatan yang akhirnya berujung pada tindak anarkis masyarakat.

Tokoh kiai sebagai pemimpin opini tidak dapat menghentikan tindak anarkis dari masyarakat. Kiai-kiai justru menjadi komunikator sentral atas terwujudnya konflik. Pandangan hidup masyarakat madura yang religius dimanfaatkan oleh tokoh kiai Sunni untuk menguatkan aksi penolakan masyarakat terhadap Syi'ah, yang distereotipkan sesat. Sedangkan Tajul sebagai pemimpin Syi'ah tetap bertahan dan meyakinkan penganutnya bahwa ajaran yang diyakini adalah ajaran yang benar dan revolusioner. Atas keberanian Tajul tersebut Tajul mulai dikenal dan dianugrahi jabatan sebagai ketua IJABI wilayah Madura oleh IJABI.

Tindakan yang dilakukan oleh kelompok Syi'ah jelas bertentangan dengan asumsi Noelle-Neumann dalam teori spiral of silence. Kelompok Syi'ah terbukti dengan sengaja melawan pendapat umum meskipun sudah mengetahui akan ada sanksi, isolasi sosial, dan konflik atas tindakan tersebut. Kendati demikian, Tajul dan Iklil mendadak menjadi terkenal sampai ke luar negeri.

\section{DAFTAR PUSTAKA}

Berger, Peter L. E Luckmann, Thomas. 1966. The Social Construction of Reality. England: Penguin Group.

Bruinessen, Martin, van. 2013. Rakyat Kecil, Islam, dan Politik. Yogyakarta: Gading.

Dharma, Ferry A.. 2016. Eklusi dan Hambatan Komunikasi dalam Konflik Sunni-Syi'ah di Sampang, Madura. Tesis. Surakarta: UNS.

Filayati, Citra Nita. 2013. "Analisis Wacana Kritis terhadap Pemberitaaan Kasus Sampang (Aliran Sunni dan Syiah) dalam Harian Suara Merdeka (edisi Agustus - September 2012)". Skripsi. Semarang: IAIN Walisongo.

Fitriani, Vita. 2013. Komunikasi Antar Budaya dalam Kehidupan Pesantren (Studi Pada Santri Etnis Jawa, Madura dan NTT Pondok Pesantren Nurul Falah Surabaya). Skripsi. Surabaya: UIN Sunan Ampel Surabaya.

Hall, Edward T. 1976. Beyond Culture. New York: Doubleday.

Husserl, Edmund. 1983. Ideas Pertaining to A Pure Phenomenological Philosophy. Translated by: F. Kersen. Boston: Martinus Nijhoff Publishers.

Jonge, Huub de. 1989. MADURA dalam empat zaman: pedagang, perkembangan ekonomi dan Islam. Jakarta: PT. Gramedia.

Judith N. Martin \& Nakayama K. 2010. Intercultural Communication in Contexts: Fitfth Edition. New York: The McGraw-Hill Companies.

Kontras Surabaya. 2012. Laporan Investigasi dan Pemantauan Kasus Syi'ah Sampang. Surabaya: Kontras.

Littlejohn, Stephen W., dan KarenA. Foss. 2011. Theories Of Human Communication. Tenth Edition. Albuquerque. New Mexico: Wadsworth Publishing Company. 
Ferry Adhi Dharma, Kritik Terhadap Teori Spiral Of Silence: Komunikasi Masyarakat Madura dalam Konflik ...

McCornack, et. al. 1996. Speaking of Informatioan Manipulation: Acritical Rejonder. Communication Monographs. Vol. 63, P. 83-92.

Muqoyyidin, Andik W. 2012. Potret Konflik Bernuansa Agama di Indonesia (Signifikansi Model Resolusi Berbasis Teologi Transformatif). Analisis. Vol. XII, No. 2. Hlm: 315-340.

Noelle-Neumann, E. 1974. The spiral of silent: a theory of public. The journal of communication. Vol. 24, No. 2, Hlm: 43-51.

Raffles, Thomas, S. 1817. The History of Java Vol. II. London: Black, Parbury, and Allen.

Samovar, Larry A., Porter, Richard E., \& McDaniel, Edwin R. 2009. Communication Between Cultures. Boston: Wadsworth.

Shoemaker, Pamela J., Breen, Michael, \& Stemper, Marjorie. 2000. Fear of Social
Isolation: Testing an Assumption from the Spiral of Silence. Irish Communication Review. Vol 8, P. 6578.

Tajfel, Henri. 1981. Human Groups and Social Categories. London: Cambridge University Press.

Vallerand, R. J., Pelletier, L. G., et. al. 1992. Azjen \& Fishbein's Theory of Reaoned Action as applied to moral behavior: A confirmatory analysis. Journal of Personality and Social Psychology. Vol. 62, No. 1, P. 98 - 109.

West, Rchard, and Turner Lynn, H. 2010. Introducting Communication Theory: Analysis Aplication fourth edition. New York: McGraw-Hill.

Withers, Bill \& Lewis D. Keami. 2003. Conflict and Communication. New York: AMACOM.

Wiyata, A. Latief. 2013. Mencari Madura. Jakarta: Bidik Phronesis Publisihing. 
